\title{
Preliminary investigation of nutrient contents in wastewater at some coastal communes of Giao Thuy district, Nam Dinh province
}

\author{
Khảo sát hàm lượng chất dinh duõng trong nước thải tại một số xã ven biển huyện \\ Giao Thủy, tỉnh Nam Định
}

Research article

Le Nhu Da ${ }^{1,2} *$, Le Thi Phuong Quynh ${ }^{1,2}$, Duong Thi Thuy ${ }^{3}$

${ }^{1}$ Graduate University of Science and Technology, Vietnam Academy of Science and Technology (VAST), 18 Hoang Quoc Viet, Cau Giay, Ha Noi, Vietnam; ' Institute of Natural Product Chemistry (INPC), VAST, 18 Hoang Quoc Viet, Cau Giay, Ha Noi, Vietnam; ${ }^{3}$ Institute of Environmental Technology (IET), VAST, 18 Hoang Quoc Viet, Cau Giay, Ha Noi, Vietnam

\begin{abstract}
Wastewater, especially non-treated wastewater from different sources is one of causes for surface and ground water pollution. However, the monitoring of wastewater quality has not been regularly implemented. This paper presents the preliminary observation results of the wastewater quality of different sources such as domestic, fishery processing, husbandry, agricultural runoff and irrigation canals in some coastal communes of Giao Thuy district, Nam Dinh province in 2017 - 2018. The results showed variation values of some variables as following: $\mathrm{pH}$ : 3.4 to 8.7 ; DO: $1.1-7.6 \mathrm{mg} / \mathrm{l}$; conductivity: $0.01->99.9 \mathrm{~S} / \mathrm{m}$; Suspended solids: $7-599 \mathrm{mg} . \mathrm{L}^{-1}$; nitrate $\left(\mathrm{NO}_{3}^{-}\right): 0.01-1.74 \mathrm{mgL}{ }^{-1}$; ammonium $\left(\mathrm{NH}_{4}{ }^{+}\right): 0.01-3.99 \mathrm{mgNL}^{-1}$, phosphate $\left(\mathrm{PO}_{4}{ }^{3-}\right):<0.01-3.05 \mathrm{mgPL}^{-1}$, total phosphorus: $0.01-5.03 \mathrm{mgPL}^{-1}$. The values of some variables such as $\mathrm{DO}, \mathrm{pH}$, nitrite, ammonium, suspended solids and phosphate at some observation time exceeded the allowed values of the Vietnamese standards for domestic wastewater quality, for industrial wastewater quality and for surface water quality. Among these different wastewaters observed, the higher contents of nutrients were found for domestic wastewater. The results provide a dataset for environmental managers in order to control of wastewater quality, especially for the coastal communes where coastal aquacultural areas are large like Giao Thuy district, Nam Dinh province.

Nuớc thải, đặc biệt là nước thải chưa qua xủ lý tù̀ nhiều nguồn thải khác nhau là một trong nhũng nguyên nhân gây ô nhiếm nguồn nước mặt và nước ngầm. Tuy nhiên việc giám sát chất luợng nuớc, lại chưa được thương xuyên thưc hiện. Bài báo trình bày kết quả khảo sát buớc đầu về chất luợng nước thải sinh hoạt, chế biến thủy sản, chăn nuôi, nông nghiệp, kênh dẫn tuoới tiêu tại một số xã ven biển thuộc huyện Giao Thủy, tỉnh Nam Định trong năm 2017 - 2018. Kết quả khảo sát cho thấy khoảng giá trị của một số thông số nhu sau: $\mathrm{pH}$ 3,4 - 8,7; DO: 1,1 - 7,6 $\mathrm{mgL}^{-1}$; độ dẫn điện: 0,01 - 99,9 S/m; chất rắn lo lửng: 7 - $599 \mathrm{mg} \cdot \mathrm{L}^{-1}$; nitrat $\left(\mathrm{NO}_{3}^{-}\right)$: 0.01-1.74 $\mathrm{mgL}^{-1}$; amoni $\left(\mathrm{NH}_{4}^{+}\right): 0.01-3.99 \mathrm{mgNL}^{-1}$; phốtphat $\left(\mathrm{PO}_{4}{ }^{3-}\right):<0,01-3,05 \mathrm{mgPL}^{-1}$ và phốtpho tổng số: 0,01- 5,03 $\mathrm{mgL}^{-1}$. Hàm luọng một số chỉ tiêu nhu $\mathrm{NO}_{2}, \mathrm{NH}_{4}{ }^{+}, \mathrm{PO}_{4}{ }^{3-}$, SS tại một số thời điểm đã vuợt quá giá trị cho phép theo các quy chuẩn nuớc thải sinh hoạt, nước thải công nghiệp và nước tưới tiêu. Trong các loại nước thải đã quan trắc, nước thải sinh hoạt có hàm luợng các chỉ tiêu dinh duỡng cao hơn. Các kêt quả nghiên cúu nhằm cung cấp cơ sở dư liệu cho các nhà quản lý về việc kiểm soát chất luợng nước thải, đặc biệt là các xã ven biển có diện tích nuôi trồng thủy sản khá lớn nhu huyện Giao Thủy, tỉnh Nam Định.
\end{abstract}

Keywords: Aquaculture, coastal communes, Giao Thuy district, nutrient contents, wasewater quality 


\section{Introduction}

Untreated wastewater strongly contributes to serious problems on surface and also ground water quality in Vietnam. Different wastewater sources from domestic, industrial, agricultural and aquacultural activities could be noted for the cause of water pollution. In Vietnam, high nutrient contents in lakes, rivers and coastal area which give favor conditions for eutrophication were observed (Duong et al., 2013; Dang et al., 2015; Duong, 2016; Nguyen et al., 2017).

Giao Thuy district, Nam Dinh province has $32 \mathrm{~km}$ of coastline which is one of advantages for aquacultural development. Coastal aquaculture in this area has contributed significantly proportion to the provincial economy. Our recent studies (Le et al., 2017; Le and Le, 2018) demonstrated that nutrient levels in coastal water for aquaculture of the Giao Thuy district were classified at mesotrophic level in general and especially at some time observed, it was at eutrophic level. As known, high nutrients may give the eutrophication potential in coastal waters in which algae bloom including harmful algae may occur, affecting the aquacultural productivity and then human health through the food chain (Chorus et al., 2000; Codd et al., 2005).

We aim to assess the nutrient contents in wastewater from different sources in the Giao Thuy district which may contribute to the nutrient trophic status of the Giao Thuy coastal sea. This paper presents the observation results of nutrients contents in different kinds of wastewater including agricultural, domestic, fishery processing, animal husbandry sources in some coastal communes of the Giao Thuy district, Nam Dinh province in the period from July 2017 to January 2018.

\section{Studied site and methodology}

\subsection{Introduction of the Giao Thuy district}

Giao Thuy has an area of $232 \mathrm{~km}^{2}$ with population of 190,921 inhabitants (data in 2016). In the district, aquaculture with a total water surface area of 5,155 ha contributed a significant proportion to the provincial economy. Seafood processing (about 40 enterprises) has been also developed for recent years. In parallel with aquacultural activities, agriculture including breeding farms (more than 200 farms) and cultivation (16,599ha, of which paddy land is of 7,491 ha and vegetable land is of 1,500 ha) play an important role for economic development ( $\mathrm{Ngoc}$ Anh, 2018). Almost wastewater is untreated and discharged to canals which then flow into the coastal zone.

\subsection{Sampling area and method}

Six sampling campaigns were conducted from July 2017 to January 2018 at different communes such as Giao Thien,
Giao An, Giao Lac, Giao Xuan, Giao Hai, Giao Long, Bach Long, Giao Phong and Quat Lam (Figure 1). Four different kinds of wastewater from domestic $(\mathrm{SH})$, fishery processing (CBTS), husbandry $(\mathrm{CN})$ and agricultural runoff $(\mathrm{NN})$ were collected. In addition, the water quality of some canals (KDCX) where different kinds of wastewaters were mixed was also observed. The samples collected from the different small/mediate/large canals in this study were represented for surface water quality in this area. The canals receive water from rivers and wastewater from different sources to form the large sewers and then flows into the sea. Noted that the canals may provide water for irrigation and other activities in this region (Table 1).

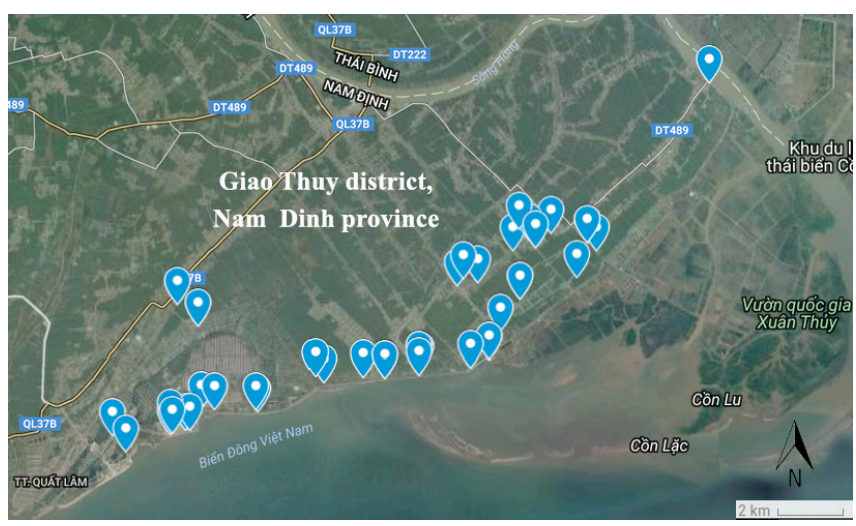

Figure 1. Sampling sites of different wastewater in coastal communes in Giao Thuy district

Table 1. Wastewater samples collected in Giao Thuy district in the period July 2017 to January 2018

\begin{tabular}{|c|c|c|c|c|}
\hline No. & Code & Wastewater types & $\begin{array}{c}\text { Number of } \\
\text { sample } \\
\end{array}$ & $\begin{array}{c}\text { Sampling } \\
\text { date }\end{array}$ \\
\hline 1 & $\mathrm{CN}$ & Husbandry & 9 & $\begin{array}{c}7,9,10 / 2017 \\
1 / 2018\end{array}$ \\
\hline 2 & $\mathrm{NN}$ & $\begin{array}{l}\text { Agricultural runoff/ } \\
\text { irrigation canals }\end{array}$ & 10 & $\begin{array}{c}7,9,10,11 / 201 \\
7 ; 1 / 2018\end{array}$ \\
\hline 3 & CBTS & Fishery processing & 9 & $\begin{array}{c}7,9,12 / 20171 / \\
2018\end{array}$ \\
\hline 4 & $\mathrm{SH}$ & Domestic & 10 & $7,9,10 / 2017$ \\
\hline 5 & $\begin{array}{c}\mathrm{KDC} \\
\mathrm{X}\end{array}$ & Canals (mixes) & 10 & $\begin{array}{c}7,9,10,11 / 201 \\
7 ; 1 / 2018\end{array}$ \\
\hline
\end{tabular}

Note: KDCX canal receives river water and wastewater from different sources to form large sewer and then flows into the sea

Different variables such as temperature $\left({ }^{\circ} \mathrm{C}\right), \mathrm{pH}$, conductivity ( ${\mathrm{S} . \mathrm{m}^{-1}}^{-}$), turbidity (NTU), and dissolved oxygen (DO, $\mathrm{mgL}^{-1}$ ) were measured in-situ by a water quality checker WQC-22A (TOA, Japan). Water samples (after well mixing) were filtered immediately by a vacuum filtration through a precombusted $\left(120^{\circ} \mathrm{C}\right.$ in $\left.2 \mathrm{~h}\right)$ glass fiber filter paper (Whatman $\mathrm{GF} / \mathrm{F}, \varnothing 47 \mathrm{~mm}$ ). All filters and filtrates were kept in a freezer $\left(<-20{ }^{\circ} \mathrm{C}\right)$ after filtration until laboratory analysis. Suspended solid (SS) contents were quantitatively determined on pre-weighed filter paper. Nutrient contents (N, P, Si) were spectrophotometrically 
measured by an UV-VIS equipment (V-630, JASCO, Japan)

by different methods described in (APHA, 2012).

\section{Results and discussion}

\subsection{Physico-chemical variables}

Table 2. Values of physico-chemical variables of wastewater samples in Giao Thuy district

$\begin{array}{ccccccc}\begin{array}{c}\text { Type of wastewater } \\ \text { and the Vietnam }\end{array} & \text { DO } & \text { pH } & \text { Temperature } & \text { Conductivity } & \text { Salinity } & \text { Suspended } \\ \text { Standards } & & (\mathrm{mg} / \mathrm{l}) & \left({ }^{\circ} \mathrm{C}\right) & (\mathrm{S} / \mathrm{m}) & \text { solids } & (\mathrm{mg} / \mathrm{l})\end{array}$

\begin{tabular}{|c|c|c|c|c|c|c|}
\hline$C N$ & $\begin{array}{c}5.0 \\
(2.8-6.7)\end{array}$ & $\begin{array}{c}7.51 \\
(6.7-7.9)\end{array}$ & $\begin{array}{c}21.9 \\
(10.2-27.7)\end{array}$ & $\begin{array}{c}0.1 \\
(0.01-0.23)\end{array}$ & $\begin{array}{c}0.05 \\
(0.01-0.12)\end{array}$ & $\begin{array}{c}64 \\
(20-190)\end{array}$ \\
\hline QCVN 62 col. B & - & $5.5-9$ & - & - & - & 150 \\
\hline CBTS & $\begin{array}{c}4.2 \\
(1.1-6.8)\end{array}$ & $\begin{array}{c}7.17 \\
(3.4-8.5)\end{array}$ & $\begin{array}{c}24.4 \\
(10.1-29.9)\end{array}$ & $\begin{array}{c}15.67 \\
(0.17->99.9)\end{array}$ & $\begin{array}{c}1.23 \\
(0.09-2.99)\end{array}$ & $\begin{array}{c}135 \\
(36-559)\end{array}$ \\
\hline QCVN 11 col. B & - & $5.5-9$ & - & - & - & 100 \\
\hline SH & $\begin{array}{c}4.6 \\
(1.4-6.4)\end{array}$ & $\begin{array}{c}7.47 \\
(6.5-8.3)\end{array}$ & $\begin{array}{c}27.9 \\
(24.8-29.2)\end{array}$ & $\begin{array}{c}0.13 \\
(0.01-0.37)\end{array}$ & $\begin{array}{c}0.06 \\
(0.01-0.19)\end{array}$ & $\begin{array}{c}55 \\
(20-128)\end{array}$ \\
\hline QCVN 14 col. B & - & $5-9$ & - & - & - & 100 \\
\hline$N N$ & $\begin{array}{c}5.2 \\
(2.7-6.7) \\
\end{array}$ & $\begin{array}{c}7.47 \\
(6.9-8.2)\end{array}$ & $\begin{array}{c}23 \\
(17.4-30.0)\end{array}$ & $\begin{array}{c}0.35 \\
(0.01-2.31)\end{array}$ & $\begin{array}{c}0.18 \\
(0.01-1.34)\end{array}$ & $\begin{array}{c}73 \\
(7-293) \\
\end{array}$ \\
\hline$K D C X$ & $\begin{array}{c}4.8 \\
(1.4-7.6)\end{array}$ & $\begin{array}{c}7.54 \\
(4.7-8.7)\end{array}$ & $\begin{array}{c}24.1 \\
(10-30.0)\end{array}$ & $\begin{array}{c}1.21 \\
(0.04-3.74)\end{array}$ & $\begin{array}{c}0.66 \\
(0.02-2.06)\end{array}$ & $\begin{array}{c}64 \\
(11-171)\end{array}$ \\
\hline QCVN 08 col. B1 & $\geq 4$ & $5.5-9$ & - & - & - & 50 \\
\hline $\begin{array}{c}\text { Average } \\
\text { Min } \\
\text { Max }\end{array}$ & $\begin{array}{l}4.7 \\
1.1 \\
7.6\end{array}$ & $\begin{array}{l}7.4 \\
3.4 \\
8.7\end{array}$ & $\begin{array}{l}24.3 \\
10.0 \\
30.0\end{array}$ & $\begin{array}{c}3.49 \\
0.01 \\
>99.9\end{array}$ & $\begin{array}{l}0.44 \\
0.01 \\
2.99\end{array}$ & $\begin{array}{c}78 \\
7 \\
559\end{array}$ \\
\hline
\end{tabular}

Note:

QCVN 62-MT:2016/BTNMT column B: It is applied to husbandry wastewater when discharged into water sources which are not not used for the purpose of domestic water supply (MONRE c, 2016).

QCVN 11-MT:2015/BTNMT column B: It is applied to Fishery processing wastewater when discharged into water sources which are not used for the purpose of domestic water supply (MONRE d, 2015).

QCVN 14:2008/BTNMT column B: It is applied to domestic wastewater when discharged into water sources which are not used for the purpose of domestic water supply (MONRE b, 2008).

QCVN 08:2015/BTNMT column B1: It is applied to surface water used for irrigation or for other uses with similar water quality requirements given in column $B 2$ (water navigation and other purposes with low quality water requirements) (MONRE a, 2015).

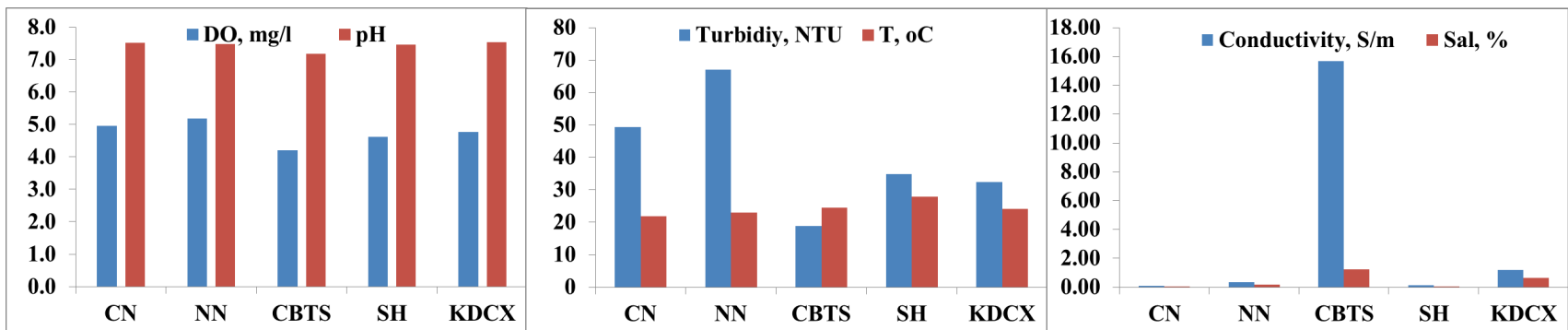

Figure 2. Average values of some physico-chemical variables of different wastewater samples in Giao Thuy district in different sampling campaigns in 2017 - 2018 
The average DO contents of 5 wastewater kinds ranged from 4.2 to $5.2 \mathrm{mg} . \mathrm{L}^{-1}$ with the lowest value observed for fishery processing wastewater $\left(4.2 \mathrm{mg} . \mathrm{L}^{-1}\right)$ and the highest value recorded for agricultural runoff $\left(5.2 \mathrm{mg} . \mathrm{L}^{-1}\right)$ (Table 2). The averages of DO values of canals KDCX and agricultural runoff $\mathrm{NN}$ were within the allowable limit of surface water standard QCVN 08:2015/BTNMT column B1 (MONREa, 2015). However, low DO values $\left(<2 \mathrm{mg} . \mathrm{L}^{-1}\right)$ were found for both canals KDCX and agricultural runoff $\mathrm{NN}$ in some observation time. Low DO value was recorded by other authors for water quality in canals in Kim Thanh district, Hai Duong province (Cao et al., 2010). For other rest kinds of wastewater, there was no allowable value proposed for DO in the Vietnamese standards. However, during different sampling campaigns, the low values of DO $\left(<2 \mathrm{mg} . \mathrm{L}^{-1}\right)$ were also observed for the samples of fishery processing CBTS and domestic wastewater SH.

$\mathrm{pH}$ values of wastewater ranged largely from $3.4-8.7$ with the highest recorded for canals (8.7) and the lowest obtained for fishery processing wastewater (3.4). The average $\mathrm{pH}$ values of all kind wastewaters in the Giao Thuy district were within the allowable limit for the respective Vietnamese standards (MONRE a, 2015; b, 2008; c, 2016; d, 2015) (Table 2)

Suspended solid values varied in a wide range, from the very low value of $7 \mathrm{mg} . \mathrm{L}^{-1}$ (for agricultural runoff) to the high value of $559 \mathrm{mg} . \mathrm{L}^{-1}$ (for fishery processing). High content of SS in wastewater from fishery processing was also recognized for the Mekong Panga Fisheries Processing Factory in Can Tho or due to shrimp and crab peeling processing (VEA, 2011) or the fish washing and grinding process (Nguyen et al., 2015). The mean SS values of CN, $\mathrm{SH}$ wastewater did not exceed the corresponding standards for husbandry wastewater QCVN 62-MT:2016/BTNMT (MONRE c, 2016) and domestic wastewater 14:2008/BTNMT (MONRE b, 2008). The mean SS value of CBTS exceeded 1.35 times than the permissible value of the QCVN 11-MT:2015/BTNMT (MONRE d, 2015). The average values of $\mathrm{NN}$ and KDCX wastewater exceeded 1.4 times and 1.28 times respectively than the allowable value of the QCVN 08-2015/BTNMT column B1 (MONRE a, 2015) (Table 2).

Table 3: The average and min-max contents of nutrients in wastewater samples in Giao Thuy district

\begin{tabular}{|c|c|c|c|c|c|c|}
\hline Type of wastewater & $\begin{array}{l}\mathrm{N}-\mathrm{NO}_{2}, \\
\text { mgL }^{-1}\end{array}$ & $\begin{array}{l}\mathrm{N}-\mathrm{NO}_{3} \\
\text { mgL }^{-1}\end{array}$ & $\begin{array}{l}\mathrm{N}^{-\mathrm{NH}_{4}}, \\
\mathrm{mgL}^{-1}\end{array}$ & $\underset{\mathrm{mg} . \mathrm{L}^{-1}}{\mathrm{Si}}$ & $\begin{array}{l}{\mathrm{P}-\mathrm{PO}_{4},} \mathrm{mgL}^{-1}\end{array}$ & $\begin{array}{l}\text { Ptot, } \\
\text { mgPL }^{-1}\end{array}$ \\
\hline $\mathbf{C N}$ & $\begin{array}{c}0.09 \\
(0.04-0.22)\end{array}$ & $\begin{array}{c}0.53 \\
(0.04-1.74)\end{array}$ & $\begin{array}{c}1.19 \\
(0.11-1.95)\end{array}$ & $\begin{array}{c}2.34 \\
(0.76-4.22)\end{array}$ & $\begin{array}{c}0.11 \\
(0.01-0.36)\end{array}$ & $\begin{array}{c}0.32 \\
(0.15-0.65)\end{array}$ \\
\hline QCVN 62 col. B & - & - & - & - & - & - \\
\hline CBTS & $\begin{array}{c}0.06 \\
(0-0.24)\end{array}$ & $\begin{array}{c}0.08 \\
(0.02-0.13)\end{array}$ & $\begin{array}{c}1.03 \\
(0.07-3.97)\end{array}$ & $\begin{array}{c}1.75 \\
(0.06-5.39)\end{array}$ & $\begin{array}{c}0.05 \\
(0.01-0.21)\end{array}$ & $\begin{array}{c}0.29 \\
(0.03-0.95)\end{array}$ \\
\hline QCVN 11 col. B & - & - & 20 & - & - & 20 \\
\hline SH & $\begin{array}{c}0.08 \\
(0-0.2)\end{array}$ & $\begin{array}{c}0.23 \\
(0.02-1.13) \\
\end{array}$ & $\begin{array}{c}1.22 \\
(0.01-3.99)\end{array}$ & $\begin{array}{c}2.49 \\
(0.04-4.1)\end{array}$ & $\begin{array}{c}0.94 \\
(0.01-3.05)\end{array}$ & $\begin{array}{c}1.81 \\
-0.4-5.03)\end{array}$ \\
\hline QCVN 14 col. B & - & 50 & 10 & - & 10 & - \\
\hline$K D C X$ & $\begin{array}{c}0.18 \\
(0.01-1.34)\end{array}$ & $\begin{array}{c}0.09 \\
(0.01-0.21)\end{array}$ & $\begin{array}{c}0.6 \\
(0.17-3.08)\end{array}$ & $\begin{array}{c}2.38 \\
(0.71-4.58\end{array}$ & $\begin{array}{c}0.06 \\
(0.01-0.47)\end{array}$ & $\begin{array}{c}0.27 \\
(0-1.15)\end{array}$ \\
\hline$N N$ & $\begin{array}{c}0.1 \\
(0.01-0.42)\end{array}$ & $\begin{array}{c}0.38 \\
(0.03-0.96)\end{array}$ & $\begin{array}{c}0.41 \\
(0.03-1.81)\end{array}$ & $\begin{array}{c}1.98 \\
(0.33-4.66) \\
\end{array}$ & $\begin{array}{c}0.06 \\
(0-0.33)\end{array}$ & $\begin{array}{c}0.27 \\
(0.01-0.73)\end{array}$ \\
\hline QCVN 08 col. B1 & 0.05 & 10 & 0.9 & - & 0.3 & - \\
\hline $\begin{array}{l}\text { Average } \\
\min \\
\max \end{array}$ & $\begin{array}{c}0.10 \\
0.001 \\
1.34 \\
\end{array}$ & $\begin{array}{l}0.26 \\
0.01 \\
1.74\end{array}$ & $\begin{array}{l}0.89 \\
0.01 \\
3.99 \\
\end{array}$ & $\begin{array}{l}2.19 \\
0.04 \\
5.39 \\
\end{array}$ & $\begin{array}{c}0.24 \\
<0.01 \\
3.05 \\
\end{array}$ & $\begin{array}{l}0.59 \\
0.01 \\
5.03 \\
\end{array}$ \\
\hline
\end{tabular}

Note: explanation for different Vietnamese standards is provided in Table 2.

\subsection{Nutrient contents}

\subsubsection{Nitrogen content}

Nitrogen in wastewater usually exists under the form of nitrite, nitrate, ammonium and organic compounds. High nitrogen content in water may accelerate phytoplankton development, of which toxic algae could produce toxins in the water environment.

The average values of nitrite contents in wastewater ranged from $0.06 \mathrm{mgL}^{-1}$ (fishery processing) to $0.18 \mathrm{mgL}^{-1}$ (canals of mixed wastewater), with an average of $0.1 \mathrm{mgL}^{-1}$ for all 5 kinds of wastewater observed (Table 3, Figure 3). Noted that there was no allowable value of nitrite contents in the specific Vietnamese standards for different kinds of 
wastewater. However, a value of $0.05 \mathrm{mgL}^{-1}$ of nitrite content has been applied for surface water in the criterion QCVN 08:2015/BTNMT column B1 (MONRE a, 2015). Comparing to this allowable value, the average of nitrite contents in canals KDCX and agricultural runoff $\mathrm{NN}$ exceeded 2.0 and 3.6 times respectively.

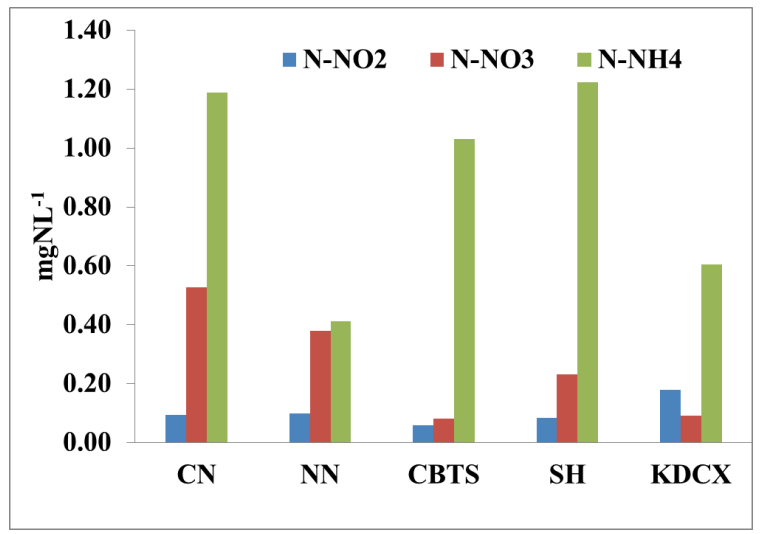

Figure 3. Average contents of nitrite, nitrate, and ammonium in 5 wastewater kinds in Giao Thuy district

The average contents of nitrate ranged from $0.08 \mathrm{mgL}^{-1}$ (fishery processing, CBTS) to $0.53 \mathrm{mgL}^{-1}$ (canals, KDCX), with an average of $0.26 \mathrm{mgL}^{-1}$. In comparison with the different specific standards (if existed) for corresponding wastewater types, nitrates contents of all samples were lower than the allowable values (Table 3 ). Nitrate contents in this study was lower than the values observed in the fishery processing of the factory Mekong Panga in Can Tho City (2.8 $\mathrm{mgL}^{-1}$ ) (Nguyen et al., 2015); or values measured in husbandry wastewater from pig farms in Vinh Loc A Commune, Binh Chanh District, HoChiMinh city (Huynh et al., 2017). The reason is that seafood processing factory and husbandry farms in Giao Thuy district was much smaller in term of production scale.

The average contents of ammonium ranged from $0.4 \mathrm{mgL}^{-1}$ (NN) to $1.2 \mathrm{mgL}^{-1}$ (domestic wastewater, $\mathrm{SH}$ ), with an average of $0.9 \mathrm{mgL}^{-1}$ for all wastewater kinds. The average value of the four wastewater (KDCX, NN, SH, CBTS) did not exceed the corresponding standards (Table 3 ). However, at some observed times, ammonium contents in canals KDCX (3.08 $\left.\mathrm{mgL}^{-1}\right)$ and agricultural runoff/irrigation canals $\mathrm{NN}$ wastewater $\left(1.81 \mathrm{mgL}^{-1}\right)$ exceeded the permissible value $\left(0.9 \mathrm{mgL}^{-1}\right)$ of the QCVN 08-2015/BTNMT column B1 for surface water (MONRE a, 2015). Compared with other studies, ammonium content in the canals in this study was 5.8 times lower than that of the Lai $\mathrm{Vu}$ commune, Kim Thanh district, Hai Duong province $\left(3.5 \mathrm{mgL}^{-1}\right.$ ) (Cao et al., 2010). The ammonium value of fishery processing wastewater in Giao Thuy district which was from small size of factories was much lower than the one of the big Mekong Panga factory in Can Tho city $\left(25 \mathrm{mgL}^{-1}\right)$ (Nguyen et al., 2015).

\subsubsection{Phosphorus content}

The average contents of phosphate ranged from $0.05 \mathrm{mgL}^{-1}$ (fishery processing CBTS) to $0.94 \mathrm{mgL}^{-1}$ (domestic wastewater - $\mathrm{SH}$ ), with an average of $0.24 \mathrm{mgL}^{-1}$ (Table 3, Figure 4). Noted that there was no allowable value of phosphate contents in the specific Vietnamese standards for husbandry and fishery processing wastewater (Table 3 ).

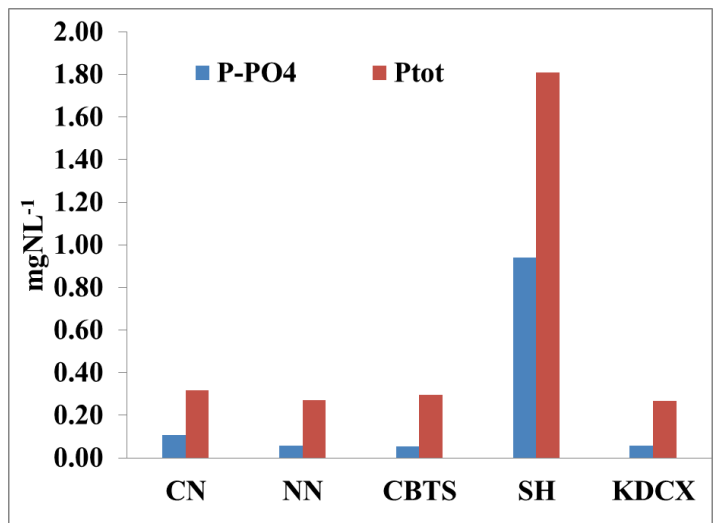

Figure 4. Average contents of phosphate and total phosphorus in 5 wastewater kinds in Giao Thuy district

The average contents of phosphate of domestic, agricultural runoff and canals were lower than the allowable values of the corresponding Vietnamese standards (QCVN 14-2015 and QCVN 08-2015). However, at some observation times, phosphate contents in $\operatorname{KDCX}(0.47)$ and NN (0.33) exceeded the permissible value of the QCVN 082015/BTNMT column B1. High phosphate contents in irrigation canals and surface water in Giao Thuy district at some time may reflect the impact of agricultural leaching or of other sources (e.g. domestic wastewater, seafood processing...). As known, phosphate content is high in domestic wastewater reflecting the use of different detergents in daily human life, especially in big city. Phosphate salts are added in detergent to increase detergent properties, to reduce water hardness, dirt back, and surface tension of the solution. In seafood processing, some companies use a tripolyphosphate solution to soak shrimp and then the waste solution is discarded, so high phosphorus content was found in the effluent (VEA, 2011). Phosphate content was also noted in agricultural runoff due to the use of chemical fertilizers in order to accelerate the plant growth. However, phosphate content may be diluted with high water volume of irrigation which may explain the low average value of the phosphate content in agricultural runoff and canals in this study.

The average contents of total phosphorus (TP) ranged from $0.27 \mathrm{mgL}^{-1}$ (agricultural runoff $\mathrm{NN}$ ) to $1.81 \mathrm{mgL}^{-1}$ (domestic wastewater $\mathrm{SH}$ ), with an average of $0.59 \mathrm{mgL}^{-1}$ for all 5 wastewater kinds. Compared to the Vietnam standards, TP of the fishery processing CBTS was within the specific standard QCVN 11-MT:2015/BTNMT (MONRE d, 2015 ). There are no allowable values of TP 
contents in the specific Vietnamese standards for other wastewater kinds.

\subsubsection{Silica content}

Silica is a major limiting nutrient for diatom growth. The average contents of dissolved silica in 5 wastewater groups ranged from the lowest $1.75 \mathrm{mgL}^{-1}$ (fishery processing CBTS) to the highest $2.49 \mathrm{mgL}^{-1}$ (domestic wastewater $\mathrm{SH}$ ), with an average of $2.19 \mathrm{mgL}^{-1}$ (Table 3, Figure 5). There is no technical standard for the silica content in different wastewater kinds. These values from agricultural runoff in this study $\left(0.33-4.66 \mathrm{mgSiL}^{-1}\right)$ were close with the ones observed in the previous study for the vegetable land in Dong Anh district, Hanoi: 1.1 - $6.6 \mathrm{mgSiL}^{-1}$ (Nguyen et al., 2014); or in different planting area of Red River basin: $0.9-$ $5.7 \mathrm{mg} \mathrm{SiL}^{-1}$ (Vu et al., 2011); or vegetable-flower planting area in the Tay Tuu - Phu Dien communes: $2.8-8.1 \mathrm{mg}$ $\mathrm{SiL}^{-1}$ (Vu et al., 2014). Noted that silica content in agricultural runoff much depends on lithology and agricultural cultivation conditions (Nguyen et al., 2014).

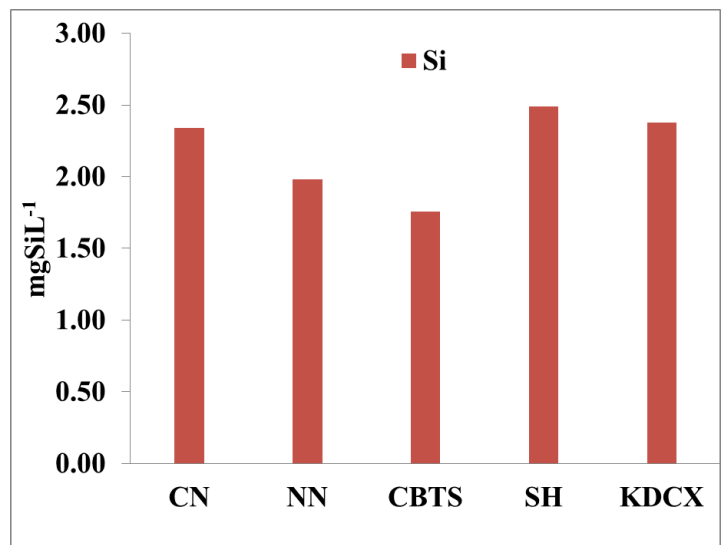

Figure 5. Average contents of DSi of 5 wastewater kinds in Giao Thuy district

\section{Conclusions}

This paper presents the observation results of the nutrient content in different wastewater kinds in some coastal communes of the Giao Thuy district, Nam Dinh province during the period from July 2017 to January 2018. The results showed that the $\mathrm{pH}$ ranged from 3.4 to 8.7 ; DO: 1.1 - $7.6 \mathrm{mgL}-1$; conductivity: 0.01 - > 99.9 S.m-1; nitrate: 0.01-1.74 mgL-1; ammonium: 0.01 - 3.99 mgNL-1; phosphate (PO43-): $<0.01-3.05$ mgPL-1, total phosphorus: 0.01 to $5.03 \mathrm{mgL}-1$. Within 5 investigated wastewater kinds, nutrients (ammonium, phosphate, and TP) contents in domestic wastewater were higher.

In general, almost the average values of nutrient contents from 5 wastewater kinds in the Giao Thuy district were within the specific Vietnamese standards. However, at some observation time, nitrite, ammonium and phosphate contents in agricultural runoff and canals exceeded the allowed
Vietnamese standard QCVN08-2015/BTNMT column B1. Low DO and high SS were also noted for different samples during sampling campaigns in 2017 -2018. Noted that the canals after receiving different wastewater flow into the coast. Thus, high nutrients at some observation time in canals in different communes in Giao Thuy district may give the risk of eutrophication in the coastal zone where aquacultural activities have been strongly developed. The results may provide dataset for helpful management and protection of water quality in the coastal area.

Our results however are the preliminary observation of nutrient contents in some kinds of wastewater in Giao Thuy district. It is necessary to expand the scope and frequency of observation, as well as to collect sufficient information on the production scale and wastewater discharge in order to give more accurate conclusions about the wastewater quality and estimating nutrient loading from Giao Thuy district to the coastal zone.

Acknowledgement: The authors thank the financial supports of the Graduate University of Science and Technology (GUST, VAST) for the project No STS.NV2017-ST01 (Dr Le Nhu Da).

\section{References}

[1] APHA (2012) Standard methods for the examination of water and wastewater $22^{\text {nd }}$ edition. Washington DC, USA.

[2] Cao TS, Luong DA, Hoang KD, Ho TLT (2010) Assessment of surface water quality in Lai $\mathrm{Vu}$ commune, Kim Thanh district, Hai Duong province. Journal of Science and Development 8(2), 296 - 303.

[3] Conley D.J, C.L. Schelske and E.F. Stoermer (1993) Modification of the biogeochemical cycle of silica with eutrophication. Marine Ecology Progress Series, 101, 179-192.

[4] Chorus I, Falconer IR, Salas HJ, Batrram J. (2000) Health caused by freshwater cyanobacteria in recreational water. Journal of Toxicology and Environmental Health 3, 323-347.

[5] Codd GA, Lindsay J, Young FM, Morrison LF, Metcalf JS (2005) Harmful cyanobacteria: from mass mortalities to management measures. In: Harmful cyanobacteria. Edited by Huisman. J, Matthijs HCP, Visser PM. Dordrecht: Springer 1-23.

[6] Dang DK, Duong TT, Nguyen TTL, Dao TS, Le TPQ, Do HLC (2014) Toxic cyanobacteria in freshwater. Publisher of Natural Science and Technology. 326 pages. ISBN: 978-604-913-218-6.

[7] Duong TN (2016) Report on the topic of "Monitoring and analyzing marine coastal environment in the North of 2016", Institute of Marine Resources and Environment, 55 pages. 
[8] Duong TT, Le TPQ, Dao TS, Pflugmacher S., RochelleNewall E., Hoang TK, Vu TN, Ho TC, Dang DK. (2013) Seasonal variation of cyanobacteria and microcystins in the Nui Coc Reservoir, Northern Vietnam. Journal of Applied Phycology, 25(4), 10651075.

[9] Huynh NP, Tran TTN, Nguyen MK, Nguyen HL (2017) The efficiency of nitrogen and phosphorus removal by upflow sludge blanket filtration (USBF) system from piggery wastewater. Journal of Forest Science and Technology 3, 85-91.

[10] Le ND, Nguyen TMH, Hoang TTH, Le TPQ, Duong TT. (2017) Preliminary results of water quality survey for aquacultural farms in coastal zone of the Giao Thuy district, Nam Dinh province. The third International Conference on Estuarine, Coastal and Shelf Studies ECSS2017, 7-10 Nov. 2017, HoChiMinh city, ISBN:978-604-73-5521-1, pp. 182-193.

[11] Le ND and Le TPQ (2018) Assessment of nutrient levels $(\mathrm{N}, \mathrm{P}$ and $\mathrm{Si}$ ) in coastal aquacultural water in some communes of the Giao Thuy district, Nam Dinh province. Journal of Chemistry (in press)

[12] Luu DD, Nguyen VH, Dang NT, Thoi NB (2011) Assessment of water quality in intensive shrimp ponds in Tran De district, Soc Trang province. Science and Technology Journal of Agriculture and rural Development (ISSN 0866-7020). 166-174.

[13] MONRE a (2015) Vietnam Ministry of Natural Resource and Environment, National technical regulation on the surface water quality QCVN 08:2015/BTNMT.

[14] MONRE b (2008) Vietnam Ministry of Natural Resource and Environment, National technical regulation on domestic wastewater QCVN 14:2008/BTNMT.

[15] MONRE c (2016) Vietnam Ministry of Natural Resource and Environment, National technical regulation on the effluent of livestock QCVN 62MT:2016/BTNMT.
[16] MONRE d (2015) Vietnam Ministry of Natural Resource and Environment, National technical regulation on the effluent of aquatic Products Processing industry QCVN 11-MT:2015/BTNMT.

[17] Nguyen TBN, Nguyen BT, Vu DA, Le TPQ, Le DN, Duong TT, Ho TC (2017) Assessment of the trophic status in some lakes within Hanoi inner city. Journal of Science and Technology, 55(1), 84-92.

[18] Nguyen TBN, Le TPQ, Nguyen TMH, Nguyen BT, Vu DA, Duong TT, Ho TC (2014) Wastewater quality in a vegetable growing area: Van Noi commune, Dong Anh district, Hanoi city. Agriculture \& Rural Development, $21,65-71$.

[19] Ngoc Anh, Development of agricultural and rural economy in Giao Thuy district (2018) http:/www.baonamdinh.com.vn/channel/5085/201804/g iao-thuy-phat-trien-kinh-te-nong-nghiep-nong-thon2523851/index.htm.

[20] Nguyen VCN, Nguyen TKN, Huynh QT and Le HV (2015) Evaluate the ability of wastewater treatment with biological filtration tank with coconut milk bed and sawdust material. Scientific Journal of Can Tho University, Part A: Natural Sciences, Technology and Environment, 37, 51-56.

[21] VEA (2011) Vietnam environment administration, Technical Documentation "Guideline for Assessment of the conformity of wastewater treatment technology and Introduction of some wastewater treatment Technologies for the Fishery, textile, paper processing", 136 pages.

[22] Vu HH, Le TPQ, Duong TT, Ho TC (2011) Dissolved silica content in agricultural wastewater in the Red River basin. Vietnam Youth Science and Technology Conference 11th., VAST, Hanoi.

[23] Vu DA, Le TPQ, Nguyen TBN, Nguyen BT, Pham QL, Seilder C and Phung TXB (2014) Wastewater quality of the agricultural region (vegetables - flowers - fruit trees) at Phu Dien and Tay Tuu wards (Hanoi). Journal of Science and Technology Development. Vol M2-2014 (17), 13-21. 